Дослідження присвячено розробиі підходу до формуванню портфелю проектів зменшення втрат у розподільчих електричних мережах. Метою роботи є обгрунтування відбору проектів зменшення втрат у розподільчих електричних мережах до портфелю проектів. В основу проектного управління зменшенням втрат покладено принципи цінністноорієнтованої організації $і$ ощадливого виробництва. Запропоновано покроковий метод формування портфелю проектів зменшения втрат, в якому в якості одиниці аналізу запропоновано використовувати фідер. Даний підхід дозволяє енергопостачальній компанії створити оптимальний портфель проектів за критеріями цінності, ризикованості і витрат.

Портфель проектів енергопостачальної компанії із зменшення втрат електроенергіï у розподільчих мережах включає комплекс технічних та організаційно-економічних проектів. Запропонований підхід до формування портфелю проектів включає шість етапів. На першому етапі відбуваеться ідентифікація компонентів портфелю, основними серед яких є ініціативи, проекти, програми, субпроекти. На другому етапі проводиться групування проектів. Для групування проектів запропоновано чотири шаблони, що характеризують технічні та організачійно-економічні проекти у портфелі. Третій етап передбачає оцінку та вибір проектів за кількісними та якісними критеріями. Для обгрунтування відбору проектів основними критеріями визначено иінність, ризикованість і витрати проекту. Аналітичний зріз проектів за даними критеріями стае основою відбору проектів. Четвертий етап передбачае визначення пріоритетів проектів y портфелі шляхом ранжування. Ранжування проводиться зіставленням значення показників цінності і привабливості проекту по групі проектів або всъого портфеля проектів. П'ятий етап передбачає балансування портфелю проектів иляхом виявлення розбіжностей між показниками груп проектів $i$ «зглажування». На базі сформованого портфеля проектів підвищуеться гнучкість управління зменшенням втрат, оскільки надаються можливості перерозподілу складу проектів за пріоритетами і регулювати використання інвестищійних ресурсів

Ключові слова: розподільчі електричні мережі, втрати електроенергї, портфельне управління, портфель проектів, пофідерний аналіз, балансування портфелю проектів, зниження втрат електроенергіi

\section{METHOD FOR FORMING THE PORTFOLIO OF PROJECTS TO REDUCE LOSSES IN ELECTRIC NETWORKS BASED ON THE LEAN APPROACH AND A FEEDER-TO- FEEDER ANALYSIS}

\author{
I. Achkasov
}

$\mathrm{PhD}$, Associate Professor* E-mail: achckasov.@ukr.net

Ye. B o iko

$\mathrm{PhD}$, Associate Professor*

E-mail: zheska11@gmail.com

T. Push k a r

$\mathrm{PhD}$, Associate Professor Department of Enterprises Economy

of Urban Economy

O. M. Beketov National University of Urban Economy in Kharkiv Marshala Bazhanova str., 17,

Kharkiv, Ukraine, 61002

E-mail: nauka_Kh@i.ua

Yu. Vykhodet s

$\mathrm{PhD}$, Associate Professor

Department of Software Engineering

National Aerospace University named after M. Zhukovsky Kharkiv Aviation Institute Chkalova str., 17, Kharkiv, Ukraine, 61070

E-mail: vyhodets17@gmail.com

*Department of Project management Kyiv National University of Construction and Architecture

Povitrflotsky ave., 31, Kyiv, Ukraine, 03037

\section{Introduction}

The state and development of the power sector as one of the main strategically important sectors of the country determines not only the possibility to address the issues of sustainable development of the national economy, but also to ensure the national security of the state. The strategy of development of the power industry of Ukraine until 2035 determines the integration of the Ukrainian power markets into the unified EU power market and inclusion of the power system of Ukraine to the EU power system. The Strategy emphasizes technological upgrading of the power sector as an important priority of development of the power industry in Ukraine [1].

Modernization and subsequent innovative development of the system of electrical networks as a part of the power sector in Ukraine at this stage faces considerable complexities. The lack of necessary investment and public funding, mecha- 
nisms for attracting additional investment from the private sector, an increase in debts for electric resources decrease the possibility of self-funding.

According to the data of the Ministry of power and coal industry of Ukraine, the production of electricity in Ukraine in 2016 significantly decreased compared with 2015: by 2,847.8 million $\mathrm{kWh}$, which made up $98.2 \%$ of the production in 2015. The decrease in electric power production in the country in recent years was affected by a significant number of objective factors. Retaining this tendency along with possible losses in the main and distributive networks poses a growing threat to the national power security.

Thus, along with an increase in electric power production in the country and necessary upgrading of the technical condition of the electric power networks, a decrease in electric power losses in all types of electric power networks necessitates the development of the electrical power supply system as a part of the power sector. At insufficient funding for technical upgrading, modernization and new construction, the use of the internal reserves of electrical networks by means of the strict control and prevention of electric power losses are the most appropriate ways of enhancing the effectiveness of electricity generation.

Increasing requirements for the technical condition of the power networks, environmental friendliness and effective use, as well as the course of Ukraine to the European integration put forward a number of important issues related to the formation of new approaches to organization and management of power production and supply with the use of the leading global practices. The project management toolset, implementation of the portfolio management of the development of functioning of power supply enterprises becomes one of the most effective approaches to the creation of the modern system of reducing the losses in electric networks and to the improvement of power supply efficiency as a whole.

Given the branching of the power supply system and complexity of the technical, technological, organizational and management processes, the problems of reducing losses must be solved in integrity. In the face of limited investment resources of power supply companies, the application of the portfolio management is a promising direction to solve this problem. The formation of the projects portfolio based on the value-oriented approach is conditioned by the necessity of taking into consideration all aspects of a power supply company, optimization of the allocation of investment resources for projects and implementation prioritization.

Most scientists associate the approaches to assessment of priority measures to reduce losses, the prevalence of those or other losses, the influence of total losses with the type of a network. The approaches to reducing losses in electric power networks are based on the classification of possible losses. With respect to distributive networks, the technological costs, formed from technical and commercial costs, are separated [2].

Thus, the object of the study is a power supply company. The subject of the study is the process of formation of the portfolio of projects for reducing the electric power losses. The characteristics of power supply companies are:

- belonging to the power sector, which is infrastructural, which is why any organizational and technological changes may not be local;

- belonging to the housing complex, which is characterized by a large number of customers, as well as explicit and implicit social burdens, limited by the regulatory policy;
- necessity to ensure stability and continuity of operation, despite the changeable conditions of the environment, including conditions of payment to suppliers and payment discipline of customers.

Accordingly, planning and implementation of the necessary measures for maintaining sustainable operation of an enterprise can and should be considered as projects and implemented as projects' portfolio management.

\section{Literature review and problem statement}

The problem in general exists in the form of the following contradiction: power supply companies, implementing projects of the infrastructure development, acquire both new customers and new sources of losses related to the theft of electricity and undue payment for it. Power supply companies need a methodological approach to the formation of the projects portfolio, which will make it possible to develop the infrastructure and work over reducing losses. That is, the portfolio of projects should help to increase meaningful indicators without deterioration of the values of other important indicators.

Reducing electric power losses in various types of electrical networks in the papers of scientists is examined in various aspects: technological, managerial, innovative, macroeconomic, etc. A considerable number of modern scholars focus their research on the technological problems of the reduction of losses, dealing with creation of new approaches to assessment of losses and modernization of the monitoring and control system. The issues of the prevention of unauthorized selection, control of payment discipline and monitoring losses at the level of interaction with customers occupy an important place in forming the measures for reducing electric power losses in electric power networks. It should be noted that most studies take into consideration the peculiarities of the electrical network, in which losses occur. Traditionally, depending on the class of voltage, electrical networks are classified into:

1) Line networks $(750-220 \mathrm{kV})$;

2) Closed networks $(110-150 \mathrm{kV})$;

3) Open (radial) networks $(150-35 \mathrm{kV})$;

4) Distributive networks $(10(6) \mathrm{kV})$;

5) Local networks $(0.38 \mathrm{kV})$.

The losses that occur in each class of electric networks need their own approach to reduce them, since the selection of the projects for every type of an electrical network will be affected by its scale and technological features $[1,2]$.

The issue of reducing power losses in various types of electrical networks is the focus of a significant number of scientific papers [3-6]. The low level of observability of electrical networks and improper quality of accounting of electric power are regarded as one of the main reasons for an increase in technological losses. The authors of paper [3] found that the necessity for formation of information support puts forth the problem of preparation of bases of the main equipment, the formation of feeder-to-feeder schemes, taking into consideration their operation under normal and emergency modes.

Paper [4] pays considerable attention to a decrease in a specific type of losses - additional electric power losses caused by the mutual influence of the modes of electric power supply systems. An increase in additional losses of electric power leads to a change in the distribution of flows and an 
increase in losses during transportation and distribution of electricity [4].

Changes of the distribution of flows during parallel operation of the line and distributive networks, specifically, in the networks with lower voltage - distributive networks cause additional power losses, which are proposed to be reduced by taking technical measures $[3,5]$.

One of the ways of reducing power losses in distributive networks is norming. The optimality criterion is electric power losses during its transportation, taking into consideration the planned value of technical losses [6]. An important element of such approach to determining the optimality criterion is taking into consideration the conditions of uncertainty and incompleteness of obtained information. To determine the planned value of technical losses, it is proposed to apply the method of neural-fuzzy modeling [6].

The fuzzy sets method is the basis of the approach to the improvement of accuracy of determining electric power losses in distributive networks. According to the authors of paper [6], the level of standard technological electrical power losses is an indicator of planning the measures for reducing technical losses of electricity. The level of non-technical losses is determined as the difference between reported and standard technological loses of electricity. Most power supply companies are oriented to this type of losses [7].

One of the main problems of evaluation of electric power losses in distributive networks is a low observability level. The authors of article [8] propose the method of evaluation of observability of separate feeders based on the probabilistic accurate calculation of variables of losses [8].

One of the possible methods for determining observability is the method for identification of electric power losses in distributive networks based on evaluation of values of the coefficients of the form of diagrams of loading separate transformation sub-stations by means of fuzzy sets [9]. When using this method, an important element is the separation of consumers' groups. The authors propose to separate domestic consumers and mixed consumers with a prevailing share of domestic consumers. Among industrial consumers, it is proposed to separate the first-type consumers with the two-shift organization of operation and the second-type consumers with the three-shift organization of operation. Industrial consumers also may have mixed forms: mixed consumers with the prevailing share of the first-type industrial consumers and mixed consumers with the prevailing share of the second-type industrial consumers [9].

The level of electric power losses in distributive networks is determined by two main components: the parameters at the basis of construction of the given network and actual modes of operation of consumers. Losses of electricity can be seen in terms of enhancement of operation effectiveness of urban electric networks [10].

Author of paper [11], while exploring the losses in electrical networks with the voltage of $0.4-0.36 \mathrm{kV}$, determines three possible methods for calculation. The most suitable method for calculation of electric power losses, according to the author, is the calculation based on complete circuits of lines. The author considers the possibility of losses calculation based on generalization of the data on networks' circuit and measurement of maximum voltage losses in the networks [11].

One of the acceptable methods for reducing technical losses in electric networks is the optimization of typologies. The repeated reconfiguration of networks minimizes complete losses due to resistance in electric networks and con- nection of additional equipment [12]. To create a modified configuration of electrical distributive systems, it is most often proposed to use genetic algorithms, such as the «particle swarm optimization algorithm» (PSO) [13]. Substantiation of planning an electric power distribution network based on the PSO algorithm is aimed at solving practical scenarios of decreasing the losses during connection of different electric power consumers [14]. Evaluation of risks of electric power losses, strengthening the counter action of a power system to electricity supply disruption, electric power losses in case of a damage, evaluation of losses through power downtime are promising directions of the study [15]. It is impossible to create the SMART system of electricity supply that maximally takes into consideration the needs of consumers and enables functional efficiency without ensuring the minimization of the negative influence on the environment [16, 17]. That is, any project on reconstruction and modernization of electric networks, aimed at reducing losses, must take into consideration the environmental component.

Thus, most of the authors, who explore the issues of electric power supply and electricity provision, emphasize the low observability level as one of the main factors that affect assessment of losses, as well as the development of measures to decrease them.

Despite considerable attention to the issues of reduction of electric power losses, most studies focus on solving the problems of technological or technical nature and are aimed at specific types of losses. Approaches to evaluation of losses also take into consideration the type of losses and the location where they occur. Solution of this issue is based on technical, technological facilities or organizational actions that involve optimization of the electricity supply system. But it is impossible to find a comprehensive solution of the problems of reduction of electricity losses taking into consideration all the above-mentioned factors only by implementing technical and technological measures.

Important factors that predetermine the measures for reducing electricity losses in distributive networks are parameters of a network, which cause mostly technological losses. Electricity consumption by not registered customers, thefts of electricity, distortion of the data on consumed electricity significantly complicate the assessment of electricity losses, contributing to the growth of commercial losses.

The estimation objectivity is greatly influenced by the organizational branching of electricity supply companies of Ukraine. Significant distortions of information about the loss of electricity are possible even at the information transmission from the initial structures (feeders) to the head enterprise.

Development of the mechanism of reducing electric power losses in distributive networks requires a systemic approach to address the technological, organizational and commercial issues. This approach should be based on the improvement of methods for power audit and the development of effective approaches to controlling these processes and to coordinating the actions regarding the implementation of measures.

In this case, we should take into consideration the specifics of operation of power supply companies, organizational structure and peculiarities of functioning of the separate units. One of the viable approaches to solving a set of problems regarding reduction of electric power losses in electric networks is the introduction of the methodology of portfolio management. 
The unresolved part of the problem in the general form is the problem of choosing the criteria for selection of projects for the portfolio of a power supply company. That is, it is necessary to develop the methodological support for controlling the process of selection of independent projects for the portfolio. The well-known and available methods for analysis of losses in distributive networks are limited by the traditionally known classifications of losses, while the methodology of analysis needs to be developed through the application of new units of analysis and observation, which will make it possible to find hidden patterns and drivers of losses.

\section{The aim and objectives of the study}

The aim of this research is to contribute to the reduction of losses in electric networks through the development of the methodological support for portfolio project management with reduction of electricity losses for an electric power supply company.

To achieve the set goal, the following tasks were set:

- to propose a new unit of analysis of electric power losses for the detection of hidden reserves of losses reduction;

- to substantiate the main criteria for selection of the projects to the portfolio of the projects for reducing electric power losses in distributive networks;

- to propose the method for the formation of the portfolio of projects for reduction of electric power losses based of the value orientation and lean production, using the new unit of analysis.

\section{Feeder as the unit of analysis and unit} of observation in studying electric power losses in distributive networks

The research into the reduction of losses in distributive electricity networks was carried out based of studying the experience and carrying out technical examination of the condition of the electrical networks of Joint-Stock Company «Zhytomyroblenergo» (Ukraine), in particular Zhytomyr RES. The data and materials of personal observations of a number of RES in Zhytomyr oblast were also used in the research. The approach to the formation of the portfolio of projects for reducing electricity losses in distributive networks is based on the data on functioning of the enterprises of the power sector in UkraineThe system of the general scientific and special methods of research was applied in the course of the study.

The general scientific methods include the method of analysis and synthesis and the method of critical analysis. The method of analysis and synthesis was applied when determining existing approaches to reduction and assessment of electricity losses. The method of critical analysis made it possible to identify the merits and shortcomings of the existing approaches to reduction of electric power losses in electric networks.

The method of systemic analysis that determined the consideration of the issue of reduction of losses in electric networks as a unified system that combines technical, commercial, organizational and managerial components was applied when considering the hierarchy of structural subdivisions of electric power distribution.

Among the special methods of this study we will separate, first, the method of project management, specifically, portfo- lio management in the formation of the portfolio of projects for reducing losses in electric networks. In the formation of the portfolio of projects for reducing losses, the method for the balanced management was also applied.

The types of losses were determined based on the method of observations, which is the most common method for estimation of electric power losses in electric networks, as well as the method of audit of the electric network observability. The evaluation of the electric network observability is becoming especially important, given the low level of observability of distributive networks and problems with information verification. The level of observability of distributive networks is significantly influenced by existence of a significant number of unaccounted customers and a low quality of input information [3].

The application of the methodology of project management in the formation of a portfolio of projects for reducing electric power losses is based on the feeder-to-feeder analysis. That is why it is proposed to use a feeder as the unit of analysis in each cycle of planning the portfolio of projects. Feeder-to-feeder analysis of electrical networks is the basis for solving a set of tasks that are intended for accumulation, studying and assessing components of electric power losses in electric networks of a company using actual, estimation and practical data. A feeder is the main structural unit of observation of losses in electric networks, as well as the main subject of project management, at which specific projects for reducing electrical power losses are aimed.

It is advisable to consider an example of the analysis of observability and losses for one of the feeders. This analysis is shown in Table 1.

Table 1

Example of a table of power system observability audit (feeder of Zhytomyr district electricity network)

\begin{tabular}{|l|c|c|}
\hline \multicolumn{1}{|c|}{ Indicator } & $\begin{array}{c}\text { Influence on } \\
\text { reduction of } \\
\text { losses, } \%\end{array}$ & $\begin{array}{c}\text { Com- } \\
\text { ments of } \\
\text { auditor }\end{array}$ \\
\hline 1. Communication (internal and external) & 10 & $\mathrm{~A}$ \\
\hline $\begin{array}{l}\text { 2. Workplace organization and visual ma- } \\
\text { nagement }\end{array}$ & 15 & $\mathrm{~B}$ \\
\hline 3. Standard operations & 10 & $\mathrm{~A}$ \\
\hline 4. Flexibility of operations & 15 & $\mathrm{~B}$ \\
\hline 5. Continuous improvements & 15 & $\mathrm{~B}$ \\
\hline 6. Error protection & 30 & $\mathrm{C}$ \\
\hline 7. Rapid re-adjustment & 25 & $\mathrm{C}$ \\
\hline 8. General maintenance of equipment & 30 & $\mathrm{C}$ \\
\hline 9. System of stocks management & 30 & $\mathrm{C}$ \\
\hline 10. Alignment of production loads & 20 & $\mathrm{~B}$ \\
\hline 11. Engineering & 20 & $\mathrm{~B}$ \\
\hline 12. System of lean accounting & 30 & $\mathrm{C}$ \\
\hline 13. System of quality management & 30 & $\mathrm{C}$ \\
\hline 14. Work with suppliers and consumers & 30 & $\mathrm{C}$ \\
\hline 15. Technical maintenance and repairs & 20 & $\mathrm{~B}$ \\
\hline 16. Productivity of a system & 30 & $\mathrm{C}$ \\
\hline Mean value of losses & 22.5 & - \\
\hline
\end{tabular}

Note: in the auditor's comments, letter A denotes the parameters of a node in norm, $B$ is the deviation from the norm, $C$ shows that there is a problem regarding losses 
The example demonstrates that most possibilities regarding the reduction of losses are formed due to: the system of error protection, general maintenance of equipment, stocks management, economical accounting, quality management system, work with suppliers, consumers and productivity of a system. The results of such audit are the basis for the formation of heuristics to determine the priorities of portfolio management of electricity supply systems.

Construction of research of electric power losses on a feeder as the unit of observation will provide a possibility to obtain the structured data that can be used to create project initiatives and relevant selection to the portfolio of projects.

\section{Theoretical and methodological principles of portfolio management to reduce electric power losses in distributive networks}

In recent years, the methodology of project management has become crucial for the implementation of tasks for improvement of functioning of enterprises and organizations of Ukraine [18]. For organizations and enterprises of the housing and communal sector, project management becomes the basis for a comprehensive solution of technological, organizational, managerial and economic problems. Based on the formation of a flexible system for responding to urgent needs of both consumers and companies, making adjustments in the operational, tactical and strategic activity of the activity involving company's project portfolio management makes it possible to implement the development strategy.
The concept of management of the projects for reducing electric power losses is based on the principles of formation of the value-oriented organization and the principles of lean production.

The value-oriented approach is based on the company's mission and aims at the creation of certain values of a company. In terms of portfolio management, this approach is implemented in the totality of the various components of the portfolio, which ensures an increase in the value of organization in totality [17].

The principle of lean production determines the actions that imply detection and reduction of the basic kinds of hidden production losses of electricity (Fig. 1).

The principle of lean production in terms of project management for power supply companies implies:

- determining the value of the finished product - voltage support in electric networks according to the technological characteristics and the needs of consumers;

- determining the value formation flows - ensuring product value formation at each of the stages: management and organization, information communication, production and distribution of electricity;

- support of sustainability of value formation flows - ensuring continuity of flows in electricity production processes;

- ensuring product consumption by the consumer - production and supply of electricity under the specific demand and prevention of production of excess electricity;

- ensuring the development and constant improvement - creation of conditions for continuous improvement of the production and supply of electricity by reducing losses, improvement of evaluation and accounting.

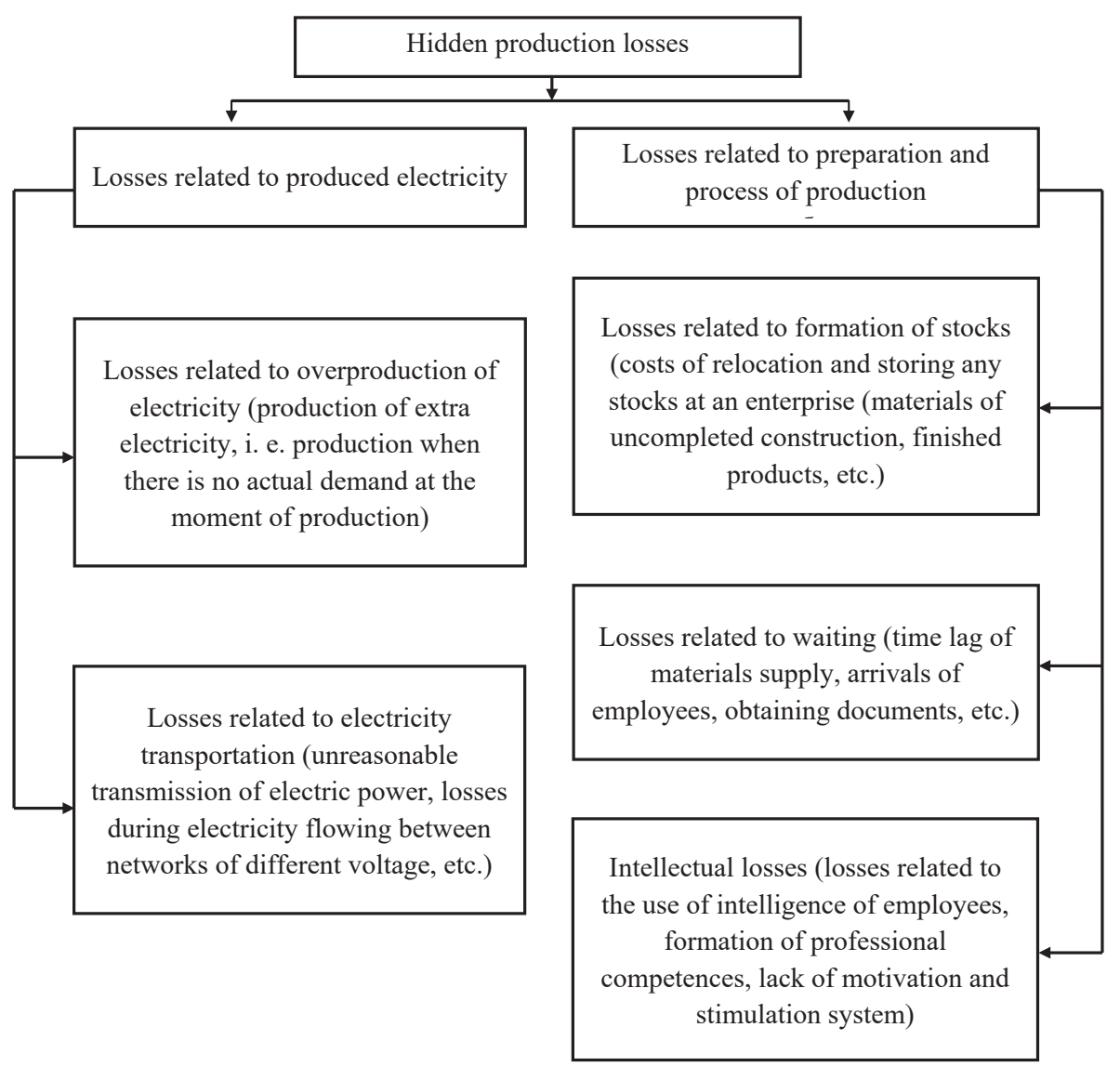

Fig. 1. Types of hidden production losses, which are the target of activities for the introduction of a system of portfolio management for lean production 
The concept of portfolio management of reducing losses in the distributive electric networks is based on the interrelation between the operation and portfolio management of the development of a power supply organization. The strategy and objectives of an organization determine the principles of the formation of a portfolio of projects, building up a certain hierarchy of projects.

Thus, the portfolio of projects of a power supply company, formed with the aim of reducing electric power losses in distributive networks, includes a range of projects with the prevalence of the technical and organizational-economic projects.

Depending on essential characteristics, the projects, aimed at the reduction of electric power losses in distributive networks, are divided into:

- according to the cost criterion - low-cost and high-cost projects;

- according to the organizational criterion - projects for every structural unit or general organizational projects;

- according to content and orientation - technological, organizational, economic, social or integrated projects.

We will note that the classification of projects in the proposed portfolio of a power supply company is conditional and can be applied based on the strategic goals of a company, its mission or specific tasks that are solved at the operational or strategic level.

An important element of the implementation of portfolio management in the practice of power supply companies is the formation of the evaluation system for estimation of power losses in electric networks. This system must accurately determine the volume of losses, take into consideration the level of observability of networks, as well as the reality of the company's activity.

An important element of portfolio management is the possibility to apply a system of methods for evaluation of electric power losses depending on the technological characteristics of electrical networks, the type of activity (operative, tactical or strategic), objectives and tasks.

The proposed hierarchy of methods for estimation of losses is based on the level of the tasks that are solved, as well as of the organizational level (Table 2).

The operative methods for determining electric power losses are used at the level of the operative activity, while analytical and estimating methods are used at any level and intelligent methods are used at the strategic level.

Branching of the methods for evaluation of electric power losses in distributive networks is caused by the tasks, which are solved during determining losses. An important aspect is also the technological feature of distributive electric networks. The selection of the evaluation method is influenced by the construction of the specific direct relationship «a power supply enterprise - a customer» at the level of distributive networks. A significant number of methods are determined by the formation of commercial losses and the level of observability of networks of this type.

An important element of the project management concept is feeder-by-feeder analysis, which makes it possible to calculate and compare the electric power supply in the distributive networks and electric power supply to consumers within a certain period. Feeder-by-feeder analysis provides a possibility to consider objective technological losses and dispatching switching, that is, forced losses.

The existence of a feeder as a primary structural element of the comprehensive evaluation of losses of a power supply enterprise, the presence of a significant number of nodes of an electric network and a significant number of consumers increases attention to the methods of the third and fourth groups.

Feeders are distributed by the observability level based on the audit of observability of an electrical system for each of its nodes. The feeder-by-feeder analysis identifies the dependence of losses in electric networks on the observability level, which makes it possible to concentrate attention and consider these options during formation of a portfolio of projects for reducing electric power losses. The structure of the feeder system for Zhytomyr REM of Joint-Stock Company «Zhytomyroblenergo» is shown in Fig. 2.

The feeder-to-feeder approach to the observability of evaluation and determining electric power losses is most often based on the method of estimation of losses of electricity supply to the main section of a feeder. Separation of feeders, audit of the observability level for each of the feeders puts forward a propriety task of taking into consideration not only determining losses at the level of the main feeder, but also comprehensive assessment for each element, summing up the result of evaluation at the level of a feeder.

Table 2

Methods for determining electric power losses in distributive networks, depending on observability level

\begin{tabular}{|c|c|c|c|c|}
\hline $\begin{array}{l}\text { No. of } \\
\text { entry }\end{array}$ & Method & Characteristics & Application & Types \\
\hline 1 & Operative & $\begin{array}{l}\text { Based on measuring current data of } \\
\text { electric power losses in the proces- } \\
\text { ses of production and distribution }\end{array}$ & $\begin{array}{l}\text { Current activity to assess actu- } \\
\text { al losses }\end{array}$ & 1) method of statistical analysis \\
\hline 2 & Analytical & $\begin{array}{l}\text { Based on comprehensive assessment } \\
\text { of data of electric power losses with } \\
\text { the use of integrating multipliers }\end{array}$ & $\begin{array}{l}\text { Current activity for comprehen- } \\
\text { sive assessment for a limited } \\
\text { number of modes }\end{array}$ & $\begin{array}{l}\text { 1) method of integral indicators; } \\
\text { 2) method of matching standard and actual in- } \\
\text { dicators }\end{array}$ \\
\hline 3 & Estimating & $\begin{array}{l}\text { Based on the use of generalized for- } \\
\text { mulas of calculation of electric po- } \\
\text { wer losses by different parameters }\end{array}$ & $\begin{array}{l}\text { Used for solving tasks of predic- } \\
\text { tion and standardization of los- } \\
\text { ses in determining actual losses } \\
\text { under conditions of uncertain- } \\
\text { ty or low observability } \\
\end{array}$ & $\begin{array}{l}\text { 1) method of element-by-element calculations; } \\
\text { 2) method of characteristic modes; } \\
\text { 3) method based on determining hours of the } \\
\text { greatest losses; } \\
\text { 4) method of average loads }\end{array}$ \\
\hline 4 & Intelligent & $\begin{array}{l}\text { Based on the use of approaches of } \\
\text { mathematical and neuro-linguistic } \\
\text { modeling, construction of artificial } \\
\text { simulation networks capable of self- } \\
\text { learning }\end{array}$ & $\begin{array}{l}\text { Used for solving prediction tasks } \\
\text { at low observability level or un- } \\
\text { certainty of external conditions }\end{array}$ & $\begin{array}{l}\text { 1) neuro-mathematic modeling; } \\
\text { 2) fuzzy logic method; } \\
\text { 3) method of genetic modeling; } \\
\text { 4) optimization methods }\end{array}$ \\
\hline
\end{tabular}




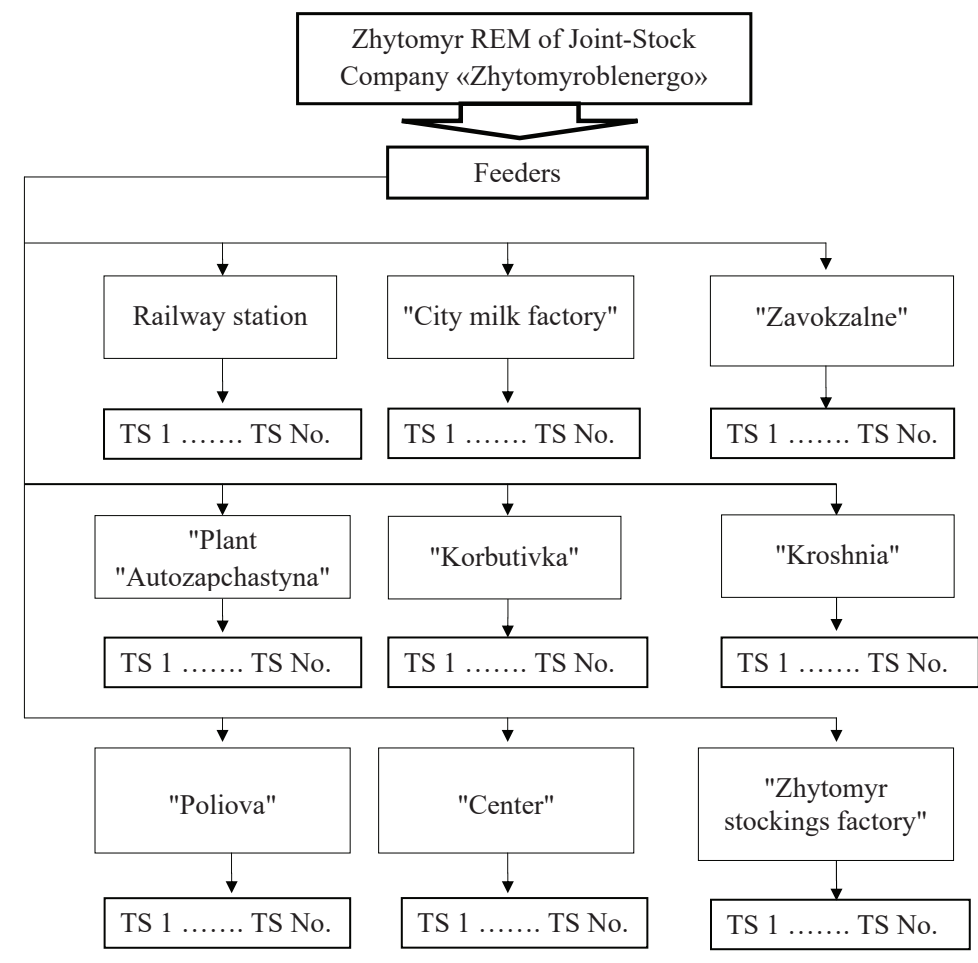

Fig. 2. Block diagram of feeders at Zhytomyr REM of Joint-Stock Company «Zhytomyroblenergo»

The formation of the proposed effective portfolio of projects for reducing electric power losses in distributive networks is based on the concept of the feeder-by-feeder analysis. Evaluation of the observability level for each feeder is carried out based on the audit of observability for each node of the electrical network.

The principles of lean production are primarily aimed at combating the main types of hidden production losses of electricity:

- losses related to overproduction of electricity. For example, production of excess electricity by order or preliminary production (before actual demand appears);

- transportation losses. Unnecessary transmission of electricity, information, documents, etc.;

- losses related to stocks. These are the costs of relocation and storing any stocks at an enterprise (materials, unfinished production, finished products, etc.);

- losses related to waiting. Any waiting (supply of materials, arrival of employees, receiving documents, etc.);

- intelligent losses. In other words, insufficient use of the intelligence of employees (engineers, equipment operators, etc.).

Here are the principles of application of lean production in power supply companies.

1. Determining the value of the final product. It is necessary to study the own products from the point of view of consumers and to understand clearly what characteristics a product must have to enjoy demand. For electric networks, it is voltage maintenance in a network.

2 . Determining the value creation flows. The value creation flows are the totalities of operations that are performed by a manufacturer for making the product. They include three stages:

- organization and management;

- information and communication with a client;

- direct manufacturing.
If any action does not form the value for the end-product, it is necessary to be changed or excluded from the general flow of creation. The result of this step is the creation of a value flow map.

3. Ensuring the sustainability of value formation flows. Products should not be moved from one working area to the other by batches. It is necessary to organize the creation flow so that there could be a continuous flow from a warehouse (raw materials, materials) to the output of finished products through all the necessary production cells.

4. Exhausting the product by a consumer. In the implementation of this step, it is necessary to ensure that those who are higher along the value formation flow should make no actions until the customer, located lower along the flow, requires making these actions. In other words, it is necessary to create the conditions for «exhausting» the end-product by a consumer under a specific demand (order).

5. Striving at perfection. The principles of lean production imply continuous improvement of the product and elimination of losses. The production process should be maximally close to the requirements of business, which involves a decrease in labor costs, time to manufacture, rent (shops, warehouses, etc.), reduction of cost value and production errors.

6. Diagnosis of the current state of power system. Diagnosis of the current state is the first step of LEAN implementation, without which it is impossible to achieve success. Before proceeding to consistent implementation of lean production and elimination of losses and «bottlenecks», it is necessary to be aware of what exactly should be corrected. To implement this step, a special mixed team is created, which includes employees of various departments and of different hierarchical levels (necessarily involving a representative of senior management), who are aware of the status of the processes at an enterprise. They conduct in-depth analysis of 
a power supply enterprise regarding 16 management elements: communication (internal and external), workplace organization and visual management, standard operations, flexibility of operations, continuous improvement, error protection, rapid readjustment, overall equipment maintenance, stocks management, production alignment, engineering, a system of lean accounting, a quality management system, work with suppliers and consumers, technical maintenance and repairs, productivity indicators.

The check-lists are used to assess the current state of an enterprise. They make it possible to approach the analysis of processes in a more systemic way and, based on in advance designed criteria, to keep track of the dynamics even over a long period.

\section{Method for the formation of a portfolio of projects for reducing electric power losses in distributive networks of the power supply enterprise}

Stage 1. Diagnosis of electric power losses based on the feeder-to-feeder analysis. The data on losses by each feeder are collected. The data should be structured by the sources of losses. The data from the neighboring feeders are analyzed and compared (if possible, clustering for subsequent formation of the initiatives of the level that is higher than a feeder).

Stage 2. Identification of the portfolio components. The list of potential components of the portfolio of projects of a power supply company is formed. Components of the portfolio can include initiatives, projects, programs, and sub-portfolios. The portfolio components are analyzed to see if they meet the strategy of a company.

Stage 3. Projects grouping. Projects are combined into groups according to four templates $\mathrm{A}, \mathrm{B}, \mathrm{C}$ and $\mathrm{D}$, which characterize technical and organizational-economic projects. The projects of one category of the portfolio have a corresponding set of criteria. Dividing projects into groups allows making portfolio management more transparent by linking projects to specific objectives in a certain way.

Stage 4. Evaluation and selection of projects. At this stage, the criteria and weighed indicators for projects are designed. The algorithm for the solution of this problem depends on the level of maturity of portfolio management in a company.

The problem of evaluation and selection of projects for the portfolio (current or future) is based on qualitative and quantitative analysis of the projects of a portfolio. Qualitative analysis is intended for selection of the most attractive projects in terms of realization of the strategy goals and objectives.

The criteria of qualitative analysis can include, for example, importance for business, controllability, urgency, innovation, etc. In this case, estimates can be based on a system of conditional metrics or weight. Quantitative analysis is intended for projects evaluation and prioritizing in terms of economic efficiency.

The most important criteria that should be paid attention to in qualitative analysis of the portfolio projects are risks, costs and value of a project for business. Projects of one group of the portfolio are compared with each other by a unified set of criteria. The weighed parameters (weights), based on which the evaluation is performed and a short list of the «recommended» projects is formed, are designed within each criterion. The similar analysis can be shown visually in the form of graphic representations.

Decision on the project selection is made using the method of analytical hierarchy.

The hierarchical structure of the selection problem takes the form shown in Fig. 3.

First, we will form the matrix of pairwise comparisons for the elements of the first level of hierarchy, that is, the matrix of pairwise comparisons of importance of criteria.

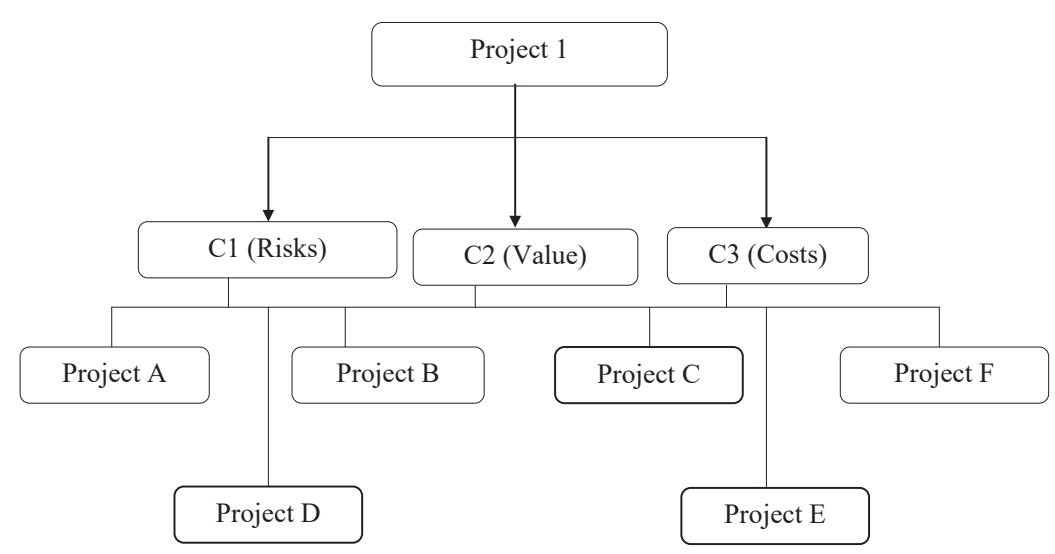

Fig. 3. Hierarchical structure of selection of a project to the portfolio

After questioning the deputy director of a company responsible for working with personnel, we obtained that:

- value (C2) is naturally-evidently better than low risks (C1) and weakly-naturally better than low cost (C3);

- low costs (C3) is weakly equally better than low risk $(\mathrm{C} 1)$.

According to the results of this survey by T. Saaty scale, a matrix of pairwise comparisons of criteria was constructed (Table 3).

Table 3

Matrix of pairwise comparisons of criteria

\begin{tabular}{|c|c|c|c|}
\hline Criterion & Risk (C1) & Value (C2) & Costs (C3) \\
\hline Risk (C1) & 1.00 & 0.17 & 0.50 \\
\hline Value (C2) & 6.00 & 1.00 & 4.00 \\
\hline Costs (C3) & 2.00 & 0.25 & 1.00 \\
\hline
\end{tabular}

Calculation of the vector of local priorities of criteria is found in Table 4.

Table 4

Calculation of the vector of local priorities of criteria

\begin{tabular}{|c|c|c|c|c|c|}
\hline $\begin{array}{c}\text { Cri- } \\
\text { teria }\end{array}$ & C1 & C2 & C3 & $\begin{array}{c}\text { Geometric average } \\
\text { by terms }\end{array}$ & Priority vector \\
\hline C1 & 1 & $\frac{1}{6}$ & $\frac{1}{2}$ & $x_{1}=\sqrt[3]{1 \cdot \frac{1}{6} \cdot \frac{1}{2}}=0.43679$ & $p_{1}^{K}=\frac{x_{1}}{\Sigma}=0.106146$ \\
\hline C2 & 6 & 1 & 4 & $x_{2}=\sqrt[3]{6 \cdot 1 \cdot 4}=2.88449$ & $p_{2}^{K}=\frac{x_{2}}{\Sigma}=0.700974$ \\
\hline C3 & 2 & $\frac{1}{4}$ & 1 & $x_{3}=\sqrt[3]{2 \cdot \frac{1}{4} \cdot 1}=0.793701$ & $p_{3}^{K}=\frac{x_{3}}{\Sigma}=0.19288$ \\
& $\sum=x_{1}+x_{2}+x_{3}=4.11499$ & \\
&
\end{tabular}


Results of the calculation of consistency index is shown in Table 5 .

Table 5

Determining the index of consistency of priorities of selection criteria

\begin{tabular}{|c|l|c|}
\hline No & Indicator & Value \\
\hline 1 & Consistency index & 0.004601 \\
\hline 2 & Consistency ratio & 0.007933 \\
\hline 3 & $\begin{array}{l}\text { Vector of local } \\
\text { priorities of crite- } \\
\text { ria relative to the } \\
\text { selection problem }\end{array}$ & $\vec{p}^{K}=(0.106146 ; 0.700974 ; 0.19288)^{T}$ \\
\hline
\end{tabular}

Next, the matrices of pairwise comparisons of alternatives for each criterion were formed.

Table 6 shows the results of comparison by the T. Saaty scale for the first criterion «Value».

Table 6

Matrix of pairwise comparisons of alternatives by $\mathrm{C} 1$

\begin{tabular}{|c|c|c|c|c|c|c|}
\hline \multirow{2}{*}{ Value } & \multicolumn{7}{|c|}{ Projects } \\
\cline { 2 - 7 } & $a$ & $b$ & $c$ & $d$ & $e$ & $f$ \\
\hline$a$ & 1.00 & 2.00 & 5.00 & 6.00 & 0.25 & 3.00 \\
\hline$b$ & 0.50 & 1.00 & 4.00 & 5.00 & 0.20 & 2.00 \\
\hline$c$ & 0.20 & 0.25 & 1.00 & 2.00 & 0.17 & 0.25 \\
\hline$d$ & 0.17 & 0.20 & 0.50 & 1.00 & 0.17 & 0.20 \\
\hline$e$ & 4.00 & 5.00 & 6.00 & 6.00 & 1.00 & 3.00 \\
\hline$f$ & 0.33 & 0.50 & 4.00 & 5.00 & 0.33 & 1.00 \\
\hline
\end{tabular}

The alternatives with the low level of risk are more attractive. The results of comparisons by the criterion «Risks» according to the scale of T. Saaty are shown in Table 7.

Table 7

Matrix of pairwise comparisons of alternatives by $\mathrm{C} 2$

\begin{tabular}{|c|c|c|c|c|c|c|}
\hline \multirow{2}{*}{ Risks } & \multicolumn{7}{|c|}{ Projects } \\
\cline { 2 - 7 } & $a$ & $b$ & $c$ & $d$ & $e$ & $f$ \\
\hline$a$ & 1 & 0.3333 & 2 & 0.1429 & 2 & 0.2 \\
\hline$b$ & 3 & 1 & 3 & 0.1667 & 3 & 0.2 \\
\hline$c$ & 0.5 & 0.3333 & 1 & 0.1429 & 1 & 0.2 \\
\hline$d$ & 7 & 6 & 7 & 1 & 7 & 5 \\
\hline$e$ & 0.5 & 0.3333 & 1 & 0.1429 & 1 & 0.25 \\
\hline$f$ & 5 & 5 & 5 & 0.2 & 4 & 1 \\
\hline
\end{tabular}

The alternatives with the low level of costs are more attractive. The results of comparisons by the criterion «Costs» according to the scale of T. Saaty are shown in Table 8.

Table 8

Matrix of pairwise comparisons of alternatives by $\mathrm{C} 3$

\begin{tabular}{|c|c|c|c|c|c|c|}
\hline \multirow{2}{*}{ Costs } & \multicolumn{7}{|c|}{ Projects } \\
\cline { 2 - 7 } & $a$ & $b$ & $c$ & $d$ & $e$ & $f$ \\
\hline$a$ & 1 & 4 & 0.5 & 0.1667 & 0.2 & 0.25 \\
\hline$b$ & 0.25 & 1 & 0.25 & 0.1429 & 0.1667 & 0.2 \\
\hline$c$ & 2 & 4 & 1 & 0.2 & 0.25 & 0.3333 \\
\hline$d$ & 6 & 7 & 5 & 1 & 2 & 2 \\
\hline$e$ & 5 & 6 & 4 & 0.5 & 1 & 3 \\
\hline$f$ & 4 & 5 & 3 & 0.5 & 0.3333 & 1 \\
\hline
\end{tabular}

Vectors of local priorities are calculated for each matrix (like for the matrix of pairwise comparisons of criteria):

$$
\vec{p}_{1}^{A}=\left(\begin{array}{c}
0.062936 \\
0.10661 \\
0.044503 \\
0.50601 \\
0.046189 \\
0.233753
\end{array}\right), \vec{p}_{2}^{A}=\left(\begin{array}{c}
0.22327 \\
0.149159 \\
0.04749 \\
0.0339444 \\
0.425646 \\
0.120485
\end{array}\right), \vec{p}_{3}^{A}=\left(\begin{array}{c}
0.060209 \\
0.030782 \\
0.085148 \\
0.365931 \\
0.283072 \\
0.174858
\end{array}\right) .
$$

Since the matrices of pairwise comparisons of alternatives are the matrices of the sixth order, $R I^{A}=1.24$.

All consistency relations are close to 0.1 , which testifies to good consistency of experts' opinions.

We will calculate the vector of global priorities of alternatives. To do this, we will construct the matrix from the vectors of local priorities of alternatives by each criterion.

$$
P^{A}=\left(\begin{array}{lll}
0.2237 & 0.0629 & 0.06020 \\
0.1491 & 0.1066 & 0.03078 \\
0.0474 & 0.0445 & 0.08514 \\
0.0339 & 0.5060 & 0.36593 \\
0.4264 & 0.0461 & 0.28307 \\
0.1204 & 0.2337 & 0.17485
\end{array}\right),
$$

and will use formula (3):

$$
\vec{p}=P^{A} \vec{p}^{K} .
$$

Thus, vector of global priorities equals:

$$
\vec{p}^{K}=(0.106146 ; 0.700974 ; 0.19288)^{\mathrm{T}},
$$

$$
\begin{aligned}
\vec{p} & =\left(\begin{array}{ccc}
0.0629 & 0.2237 & 0,06020 \\
0.1066 & 0.1491 & 0,03078 \\
0.0445 & 0.0474 & 0,08514 \\
0.5060 & 0.0339 & 0,36593 \\
0.0461 & 0.4264 & 0,28307 \\
0.2337 & 0.1204 & 0,17485
\end{array}\right) \cdot\left(\begin{array}{c}
0.106146 \\
0.700974 \\
0.19288
\end{array}\right)= \\
& =\left(\begin{array}{c}
0.174804 \\
0.12181 \\
0.054437 \\
0.148086 \\
0.3357869 \\
0.142995
\end{array}\right) .
\end{aligned}
$$

Alternative 5, that is project e, corresponds to the maximum component of the vector of global priorities.

Fig. 4 shows an analytical sample for the projects of two groups of the portfolio at comparison of the Value (vertical axis) - Risks (horizontal axis) - Costs (dimensions of a circle) parameters on the bubble diagram. As a result, we need to select from the following 6 projects.

The diagram shows that:

- project «e» has high value and is characterized by moderate costs and its implementation is associated with low risks;

- project «c» is associated with high costs and low value for business, in addition, it is highly risky. This project is 
the least attractive, and in this case, it is necessary to make a decision: either not to include it in the portfolio, or redirect it by changing its objectives and parameters to enhance its attractiveness;

- project «f» is characterized by moderate costs, moderate risks and high value. The project is recommended to be included into the portfolio of projects.

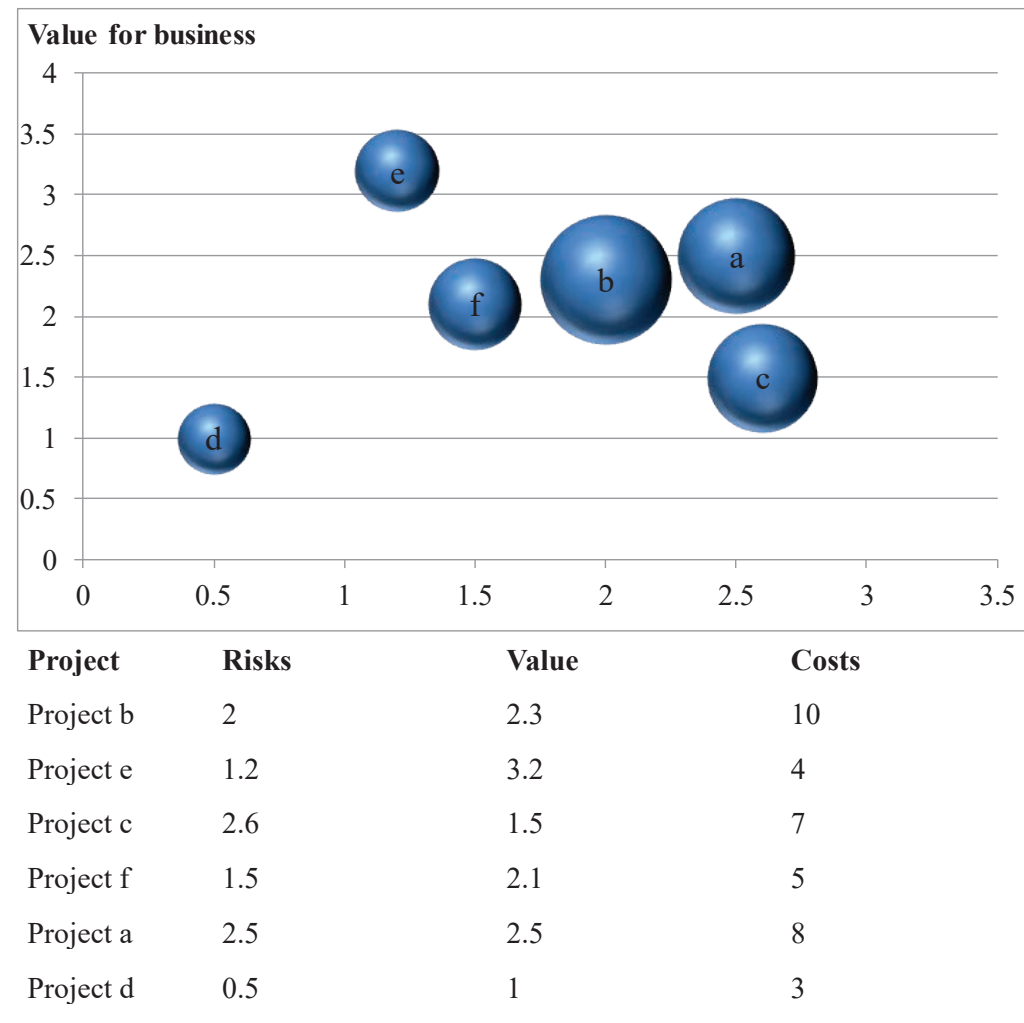

Fig. 4. Analytic sample for the projects of two groups of the portfolio
Stage 6. Portfolio balancing. The purpose of projects' portfolio balancing is to determine the following criteria for selection of projects:

1) selected portfolio components support the organization in achieving its strategic objectives and in obtaining specific benefits;

2) an accessible method for evaluation to what extent a portfolio is consistent with acceptable risks;

3 ) how the portfolio is balanced;

4) how the structured and consistent method for assessment and consistency of the totality of portfolio components is used;

5 ) whether there is comparability among portfolio components of different types.

Potential components of the portfolio should be selected for inclusion into the portfolio by the results of evaluation of the contribution to achievement of strategic objectives within the observability limits, based on the use of the established selection criteria.

This selection includes the assignment of the priority to each of the potential components of the portfolio and balancing of the general content.

The diagram of the balancing criteria is shown in Fig. 5.

The components of the portfolio of projects for reducing technological losses of electricity were selected based on the criteria, determined in Fig. 3 (Table 9).

Balancing the projects' portfolio involves detection of significant differences between the indicators of the groups of the portfolio and «smoothing». Graphical display of portfolio balancing is represented in the form of a petal diagram (Fig. 6).
With respect to the above principle, it is possible to select the best projects in the group of the portfolio.

Stage 5. Prioritization of projects in the portfolio. The projects, selected at the stage of qualitative and quantitative analysis, are ranked according to the established criteria that characterize, for example, the importance and urgency of implementation. Based on the value of these criteria, the rating of the components in the portfolio group is determined. Projects' priorities within a group can be placed based on the comparison of the values of indicators of value and attractiveness of the project with the total value of selected indicators by the portfolio group or by the whole portfolio. The sets of indicators for comparison can match the set, used at the stage of quantitative analysis of projects. Prioritization of the portfolio projects based on the corresponding criteria makes it possible to select the projects that will bring the greatest benefit for a company, significant for the results of implementation of the entire portfolio or the most adapted to the influence of external conditions.
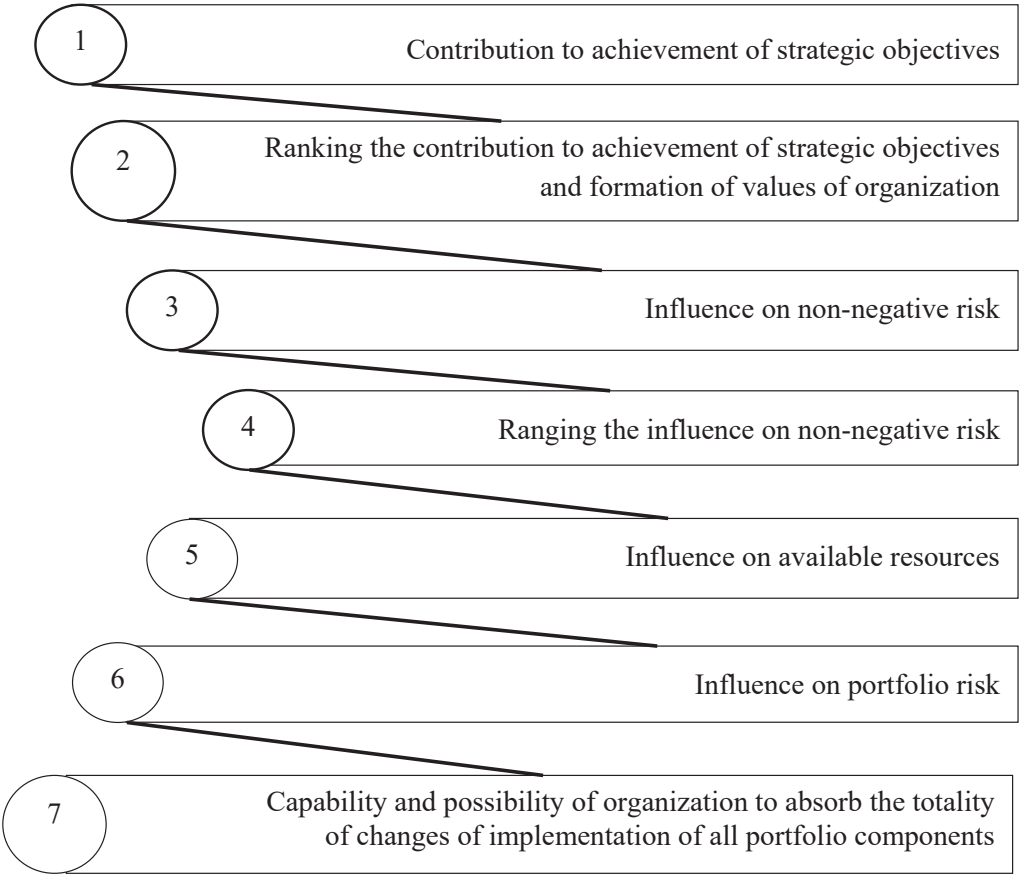

Fig. 5. Diagram of criteria of balancing the portfolio of projects for reducing technological losses of electricity 
Table 9 the type and the level of occurrence of losses. The technical

Source data to balance projects

\begin{tabular}{|c|c|c|c|c|}
\hline Portfolio & $\begin{array}{c}\text { Total costs } \\
\text { of projects } \\
\text { of the } \\
\text { group }\end{array}$ & $\begin{array}{c}\text { Average } \\
\text { estimate of the } \\
\text { group by crite- } \\
\text { rion of value }\end{array}$ & $\begin{array}{c}\text { Average } \\
\text { estimate } \\
\text { of risk }\end{array}$ & $\begin{array}{c}\text { Percentage } \\
\text { of projects of } \\
\text { the group in } \\
\text { the portfolio }\end{array}$ \\
\hline Group A & 150 & 50 & 80 & 40 \\
\hline Group B & 52 & 80 & 40 & 25 \\
\hline Group C & 122 & 60 & 70 & 20 \\
\hline Group D & 48 & 40 & 30 & 15 \\
\hline
\end{tabular}

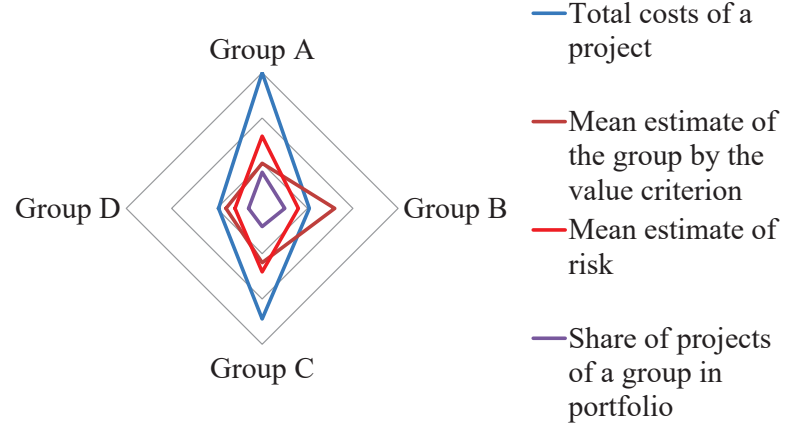

Fig. 6. Balancing the portfolio of projects

The example above (Fig. 6) indicates that highly risky projects of group A with the considerable volume of investments but the lower value for business take the largest share in the total portfolio. In this regard, it is recommended to reduce investments in this group. The projects of group B are also associated with risks and costs of implementation, but in this case, the projects of this group are extremely important to a company, which is proved by the high weight of the projects of the group by the criterion of value. In this case, for the balance, it is necessary to add other projects with moderate risks and significant commercial effect to group $\mathrm{B}$, which is achieved in a short period of time.

An important aspect of portfolio balancing is planning the resource provision by the portfolio components. In this case, it is necessary to take into consideration the moment the need for resources for a specific project appears. The resource provision of the portfolio must be planned according to the established resource limitations, which are permissible to use for a specific project in the period. A similar approach may be implemented using the known software, such as MS Project. The current portfolio of projects is formed and accepted for implementation in the framework of portfolio balancing, based on analysis of the logic of components alternations. Thus, the method for the formation of the balanced portfolio of projects for reducing electricity losses of a power supply company was proposed. The peculiarity of the method is that it proposed using the feeder as the unit of observation of losses in electric networks and a unit of analysis when creating components of the portfolio. Due to this, we proposed the step-by-step method for selection of projects for reducing losses in electric networks as the development of the application of the method of hierarchy analysis.

\section{Discussion of results of studying the tools of portfolio management for reducing electric power losses in distributive networks}

The problem of reducing electric power losses is solved both at various stages of their emergence, and depending on measures that are aimed at reducing the technological losses, improvement of information accounting and transmission, prevention of losses in running between the networks of different voltage do not offer a possibility to form a comprehensive approach to solution of this problem. It is necessary to take into consideration that the reduction of electric power losses in distributive networks implies the influence not only on technological, but also on commercial losses.

The merit of the approach to reducing electric power losses is that a set of measures is aimed primarily at the mission and strategic goals of an enterprise. Reduction of losses in this approach is not only a means of performance improvement, but also a certain tool to attract internal reserves. For modern power supply companies, the principle of lean production puts forward the new value guidelines, without associating of which with the objectives of the current activity, it is impossible to form a plan for effective actions.

The merits of the proposed method for selection of losses reduction projects for the portfolio include determining a set of projects, based of the tasks a company faces. Portfolio management provides a possibility, depending on the goal, to combine the projects that are different by content, scale and place of implementation. Portfolio ranking and balancing make it possible to redistribute limited investment resources depending on the project priority, which in terms of investment deficit and self-funding problems enhances efficiency of the losses reduction management. The merits of the proposed approach to formation of the portfolio of projects include a wide range of possibilities of applications: from operative management of the current activity to the strategic management of the development of power supply companies. But this research requires subsequent development, since the choice of the criteria for selection of projects, a distinct correlation with quantitative indicators requires additional work.

The proposed approach to the formation of a portfolio of projects for reducing losses is a continuation of earlier studies on the application of the methodology of project management in the activity of the enterprises of the housing and communal sector. Developments regarding the formation of a portfolio of projects for reducing electric power losses are aimed at application in the practical activity of power supply companies and can become the basis for the introduction of innovative project management tools. In the future, within the development of the proposed study, we are planning to develop a system of qualitative and quantitative indicators, based on which companies will be able to select the projects depending on the content, scope and the place of implementation of a particular project.

\section{Conclusions}

1. It was proposed to select a feeder as the new unit of analysis of electric power losses in distributive networks in order to create initiatives to reduce losses. It is substantiated by the fact that a feeder can be used as a unit of observation of losses and for obtaining structured data that make it possible to discover hidden reserves of reduction of electric power losses. It was shown that the feeder-to-feeder analysis ensures the integration of observation data into the process of creation of portfolio components of reducing losses. In this case, the procedure of analysis acquires the following features: the infrastructure of distributive networks and the 
feeder-to-feeder analysis enable detection of reserves and creation of initiatives not only at the level of feeders, but also for the clusters of neighboring feeders. That is, a feeder as the unit of analysis for planning and assessing the feasibility of projects is convenient, it does not require extra efforts for structuring the observation data and makes it possible to find the patterns of losses for clusters.

2. It was proposed to use the value, risks and costs as the main criteria for selection of projects, because they are semantically integrated into the project management methodology and are clear for the respondents - the experts from enterprises, they can be used for projects with the different areas of knowledge. The procedure for the selection of projects under these criteria was demonstrated and it was shown that all relations of consistency are close to 0.1 , which indicates good consistency of the opinions of experts. The selection procedure in this case should contain a pairwise comparison of criteria and calculation of consistency relationships.
3. We proposed the method for the formation of a balanced portfolio of projects for reducing electric power losses of a power supply company, the essence of which lies in complexing some tools: diagnosis of losses that is based on the feeder-to-feeder analysis and makes it possible to create the portfolio components, the method of analysis of hierarchies for selection of components to the portfolio, portfolio balancing due to alignment of resources. The peculiarity of the method is that it was proposed to apply a feeder as the unit of observation of losses in electric networks and the unit of analysis when creating the portfolio. Due to this, we proposed the step-by-step method for selection of the projects for reducing losses in electric network as the development of the application of the method of hierarchy analysis. The application of the method was demonstrated on the example of PrAT EK «Zhytomyroblenergo» (Ukraine). The method can be used by power supply enterprises of energy supply, which have the technical possibility to observe losses by feeders.

\section{References}

1. Enerhetychna stratehiya Ukrainy na period do 2030 roku vid 24.07.2013 No. 1071. Verkhovna Rada Ukrainy. URL: http://zakon3. rada.gov.ua/laws/show/n0002120-13

2. Burbelo M. Y., Melnychuk L. M. Stymuliuvannia zmenshennia vtrat v elektrychnykh merezhakh: monohrafiya. Vinnytsia, 2008. 110 p.

3. Lezhniuk P. D. Informatsiyne zabezpechennia rozrakhunkiv vtrat elektroenerhiyi u miskykh elektrychnykh merezhakh // Svitlotekhnika ta elektroenerhetyka. 2008. Issue 1. P. 51-57.

4. Lezhniuk P. D. Zmenshennia dodatkovykh vtrat elektroenerhiyi v neodnoridnykh elektrychnykh merezhakh // Visnyk Khmelnytskoho natsionalnoho universytetu. 2013. Issue 5. P. 194-200.

5. Lezhniuk P. D. Zmenshennia dodatkovykh vtrat elektroenerhiyi v elektrychnykh merezhakh za dopomohoiu kros-transformatoriv // Enerhetyka. 2014. Issue 3. P. 7-14. URL: http://nbuv.gov.ua/UJRN/eete_2014_3_3

6. Lezhniuk P. D. Optymalne keruvannia normalnymy rezhymamy elektroenerhetychnykh system kryterialnym metodom z vykorystanniam neirochitkoho modeliuvannia // Visnyk Vinnytskoho politekhnichnoho instytutu. 2012. Issue 1. P. 127-130.

7. Kulyk V. V., Pyskliarova A. V., Pyskliarov D. S. Metody ta zasoby pidvyshchennia tochnosti vyznachennia vtrat elektroenerhiyi v rozpodilnykh merezhakh 10(6) kV z vykorystanniam nechitkykh mnozhyn: monohrafiya. Vinnytsia: UNIVERSUM-Vinnytsia, 2011. 146 p.

8. Kulyk V. V. Vyznachennia vtrat elektroenerhiyi v rozpodilchykh merezhakh 10 (6) Kv za umov nedoskonaloi vykhidnoi informatsiyi // Visnyk KDU imeni M. Ostrohradskoho. 2010. Issue 4 (63). P. 103-106.

9. Avtomatyzatsiya rozrakhunku vtrat elektroenerhiyi v rozpodilnykh merezhakh 10 (6) Kv / Kutin V. M., Kulyk V. V., Pyskliarov D. S., Lonska O. V. // Naukovi pratsi VNTU. 2008. Issue 3. P. 1-7.

10. Maliarenko V. A. Ekonomiya elektroenerhiyi i znyzhennia vtrat v elektrychnykh merezhakh // Enerhozberezhennia. Enerhetyka. Enerhoaudyt. 2012. Issue 08 (102). P. 9-14.

11. Sadovskaya A. O poteryah elektroenergii v elektricheskih setyah 0,4 kV // Energetika. 2013. Issue 2 (45). P. 22-24.

12. Cavalheiro E. M. B., Vergílio A. H. B., Lyra C. Optimal configuration of power distribution networks with variable renewable energy resources // Computers \& Operations Research. 2018. Vol. 96. P. 272-280. doi: https://doi.org/10.1016/j.cor.2017.09.021

13. Distribution Systems Reconfiguration using a modified particle swarm optimization algorithm / Abdelaziz A. Y., Mohammed F. M., Mekhamer S. F., Badr M. A. L. // Electric Power Systems Research. 2009. Vol. 79, Issue 11. P. 1521-1530. doi: https:// doi.org/10.1016/j.epsr.2009.05.004

14. A coordinated planning framework of electric power distribution system: Intelligent reconfiguration / Kumar D., Singh A., Mishra S. K., Jha R. C., Samantaray S. R. // International Transactions on Electrical Energy Systems. 2018. Vol. 28, Issue 6. P. e2543. doi: https://doi.org/10.1002/etep.2543

15. Castillo A. Risk analysis and management in power outage and restoration: A literature survey // Electric Power Systems Research. 2014. Vol. 107. P. 9-15. doi: https://doi.org/10.1016/j.epsr.2013.09.002

16. Optimization of electric power systems with cost minimization and environmental-impact mitigation under multiple uncertainties / Nie S., Huang Z. C., Huang G. H., Yu L., Liu J. // Applied Energy. 2018. Vol. 221. 249-267. doi: https://doi.org/10.1016/j.apenergy.2018.03.194

17. Min D., Ryu J., Choi D. G. A long-term capacity expansion planning model for an electric power system integrating large-size renewable energy technologies // Computers \& Operations Research. 2018. Vol. 96. P. 244-255. doi: https://doi.org/10.1016/j.cor.2017.10.006

18. Achkasov I. A., Pushkar' T. A. Project management of energy saving in housing and communal services of Ukraine // Eastern-European Journal of Enterprise Technologies. 2011. Vol. 3, Issue 12 (51). P. 61-65. URL: http://journals.uran.ua/eejet/article/view/2471/2272

19. Semko I. B. Metodyka formuvannia portfelia proektiv pidpryiemstv enerhetychnoi haluzi // Upravlinnia rozvytkom skladnykh system. 2014. Issue 17. P. 60-64. 